\title{
Court ruling has its dangers
}

by Colin Norman, Washington

Thanks to a little-noticed ruling of the Federal Appeals Court in Washington DC, research proposals contained in any grant application submitted to the federal government must be disclosed to anybody who asks to see themincluding another scientist working in the same field.

Since grant applications, particularly those submitted to the National Institutes of Health, usually contain a fairly detailed description of the proposed experiments and how they will be carried out, several scientists reacted with some alarm when informed of the court decision last week. And, within NIH itself, there is a general feeling that the ruling will affect the way in which grant applications are written and reviewed.

Brought by a public interest law group called the Washington Research Project Inc., the court case itself involved eleven specific grant applications for research into the effects of psychotropic drugs on children with learning disabilities.

A lower court judge ruled in November last year that the Freedom of Information Act (FIA) requires that not only the grant applications but also the reponts of peer-review groups which rate them according to their scientific merit, should be made public. The Appeals Court decided last week, however, that while the grant applications should, indeed, be publicly available, the confidentiality of peer-review reports should be preserved.

A fight is now likely to ensue over exactly how the ruling should be interpreited. Although a final determination had not then been reached, government lawyers suggested last week that since the eleven grant applications in question had all been approved and funded by the National Institute of Mental Health, the decision probably does not apply to applications which are still pending. But a lawyer for the Washington Research Project, citing language in the decision which refers to "approved or pending" applications, argues that it does.

In any case, even if the ruling does apply only to approved grants, it would still cause a radical break from esiablished NIH practice and hold some important implications.

Finst, there is the possibility of plagiarism of research ideas. According to the Appeal Court judge, the government lawyers took "pains to argue that biomedical researchers are really a mean-spirited lot who pursue self-interest as ruthlessly as the Barbary pirates did in their own chosen field".
They argued, in fact, that a scientist would be able to get complete details of a competitor's experimental designs simply by asking NIH for them, conducting the experiments himself, and getting into print with the results before the hapless originator of the idea had been able to do so.

There are, however, rather more subtle ways in which the decision could influence the course of scientific research. It has been argued that one result will be that grant applicants will be less than explicit in giving detaiis of their proposed experiments. Not only would that make the job of scientific review committees more difficult, but it could also favour those scientists who have an established track record.

Another possible consequence, cited by the Association of American Medical Colleges in a court brief, is that "pharmaceutical companies could periodically review NIH and NIMH files for the purpose of converting research findings to commercial use, thereby converting the government into a conduit of free research and methodologies for private gain". Furthermore, sinc the drug companies would also be made aware of what research the government is funding, they would be less inclined to invest in those areas, "thus discouraging independent biomedical research", the AAMC argues.

On the other side of the coin, however, it can be argued that taxpayers have a right to know exactly how the federal government is spending their money, and it would be contrary to the spirit of open government embodied in the Freedom of Information Act to keep research applications confidential.

$\mathrm{Be}$ that as it may, the government will probably appeal the case to the Supreme Count, although no decision has yet been made on that score. Alternatively, Congress could attach an amendment either to the Freedom of Information Act, or to other legislation such as appropriations bills, to preserve the confidentiality of grant applications. A move by Senator Robert Dole earlier this year to attach just such an amendment to the Freedom of Information Act was, however, turned back pending the court decision, and Congress is, in any case, unlikely to pass such a measure without first giving it some study at the committee level.

\section{Israeli jobs for Soviet scientists}

from Nechemia Meyers, Rehovot

WiLl Israel be able to absorb the 60,000 Jews a year, many of them engineers and scientists, who will reportedly be permitted to leave the U.S.S.R. under the terms of an unpublished agreement between the U.S. government and the Soviet government? To be sure, there is no shortage of jobs in Israel. The building trades, agriculture, industry and various services could absorb thousands of newcomers each year. However, positions are not so readily available for university graduates. Even now, according to Absorption Ministry Director General Menahem Sherman, 1,400 are without immediate prospects of a job.

No one knows how many scientists and engineers will be allowed out, but a large number could appear on the Israeli labour market in a relatively short period of time. Indeed, there are more Jewish scientists and engineers in the Soviet Union-an estimated 100,000 - than in Israel, and Israel, of course, has an infinitely smaller economy in which to absorb them.

Israel's National Council for Research and Development has already established a special committee to approve Government allocations to new research units based primarily on immigrant scientists. Groups recently established with NCRD aid include one designed to foster the industrial utilisation of Negev Desert chemicals, another working on tools using radiation for inspection purposes and a third in the field of biomedical engineering.

Dr Vladimir (Ze'ev) Zaretskii (until 1971 a member of the Institute for the Chemistry of Natural Products of the U.S.S.R. Academy of Sciences in Moscow, and now in charge of the Weizmann Institute's Organic Mass Spectrometry Centre) believes that a large number of his former colleagues can be absorbed and help lsrael's development at the same time.

"Their place," he says, "is in industrial research. Thousands upon thousands of talented Jewish scientists and engineers work at centres of applied science. Their talents could be utilised by existing Israeli companies or by specially created new ones."

While welcoming the NCRD bodies, Dr Zaretskii believes an even closer link should be forged between industry on the one hand, and immigrant scientists and engineers on the other. He suggests partnerships that would bring together the research knowhow of the Russians with the business knowhow of Israelis and Americans. "People trained in the U.S.S.R. don't understand Western concepts of profit margins and marketing. But they do know how to work," Zaretskii says.

Certainly this isn't the best time for industrial expansion. Israel's resources are strained to the limit and beyond by defence needs. Moreover, it is becoming increasingly difficult to export goods at a time when world markets are shrinking and country after country is sliding into a recession. 